\title{
Purification and characterization of L-histidine aminotransferase from nikkomycin-producing Streptomyces tendae Tü901
}

\author{
UlRiCh RoOS and Christiane BoRMANN*
}

\begin{abstract}
Institut für Mikrobielle Genetik, Medizinisch-Naturwissenschaftliches Forschungszentrum der Universität Tübingen, Tübingen, Germany
\end{abstract}

(Received 9 March 1993; revised 28 May 1993; accepted 16 June 1993)

\begin{abstract}
Cell extracts of Streptomyces tendae grown in nikkomycin production media contained an enzyme (HisAT) that transaminated L-histidine as the sole amino substrate with pyruvate as the amino group acceptor. HisAT was purified about 190-fold from the crude extract of $S$. tendae. The enzyme was determined by gel filtration and SDSPAGE to be a homodimer with a subunit molecular mass of approximately $45 \mathrm{kDa}$. The aminotransferase had maximum activity at pH 7.0 and $37^{\circ} \mathrm{C}$. The enzyme was highly specific for L-histidine; pyruvate, 2-oxobutyrate, 2-oxovalerate and 2-oxocaproate were used as keto acceptors to about the same extent. The reaction mechanism was ping-pong. The $K_{\mathrm{m}}$ values for L-histidine and pyruvate, determined from Lineweaver-Burk plots, were $25 \mathrm{mM}$ and $10 \mathrm{mM}$, respectively. Neither cell extracts of non-producing $S$. tendae mutants nor extracts of Streptomyces lividans, a species that does not synthesize nikkomycins, showed transaminating activity with a narrow substrate specificity for L-histidine as the amino donor. This strongly suggests that the formation of HisAT is essential for nikkomycin production.
\end{abstract}

\section{Introduction}

Aminotransferases play a major role in the metabolism of most amino acids. Many aminotransferases have broad and overlapping substrate specificities and function in more than one biochemical pathway. In addition, they catalyse freely reversible reactions providing a high degree of versatility (Jensen \& Calhoun, 1981). While aminotransferases that utilize aromatic amino acids in the presence of a 2-oxo acid acceptor are widely distributed in micro-organisms (Gelfand \& Steinberg, 1977; Paris \& Magasanik, 1981 a; Kradolfer et al., 1982; Whitaker et al., 1982; Lee \& Desmazeaud, 1985; Lewis Kittell et al., 1989), there are only a few reports of histidine aminotransferases (HisAT). Some aromatic aminotransferases (AAT) are also able to utilize histidine as amino substrate. A multispecific AAT using histidine as amino donor has been detected in extracts of Escherichia coli B grown under conditions of nitrogen limitation (Wickramasinghe, $1969 a, b$ ). Its postulated physiological role was to scavenge nitrogen from histidine and other amino acids during nitrogen deprivation. In Klebsiella aerogenes (K. pneumoniae) amino-

\footnotetext{
*Author for correspondence.

Abbreviations: AAT, aromatic aminotransferase; HisAT, histidine aminotransferase.
}

transferase I plays an essential role in the utilization of tryptophan and phenylalanine as sources of nitrogen. It can also transaminate histidine, although its affinity for this amino acid is very low (Paris \& Magasanik, $1981 b$ ). Furthermore, an AAT acting on aromatic amino acids and histidine has been purified from extracts of $R h i-$ zobium leguminosarum (Perez-Galdona et al., 1992). In contrast, the L-histidine-2-oxoglutarate aminotransferase from Pseudomonas testosteroni, which is essential for the utilization of imidazolyl-L-lactate as sole carbon source, exhibits great specificity for histidine as amino donor (Hacking \& Hassall, 1975).

In crude protein extracts of nikkomycin-producing $S$. tendae Tü901/hut-11 separated on polyacrylamide gels, we detected a protein exhibiting transaminase activity with L-histidine in the presence of pyridoxal phosphate and pyruvate (Roos et al., 1992). This protein did not use aromatic amino acids as amino substrates. During growth of $S$. tendae in nikkomycin production medium, HisAT activity was at its maximum in mycelium harvested at the onset of the nikkomycin production phase. As L-histidine and imidazole pyruvate are precursors of the 4-formyl-4-imidazolone base of nikkomycins (Schmidt \& Pape, 1985; Kamps, 1989), it seemed that the HisAT might be involved in the nikkomycin biosynthetic pathway. In the present paper we relate the formation of HisAT protein to nikkomycin production, 

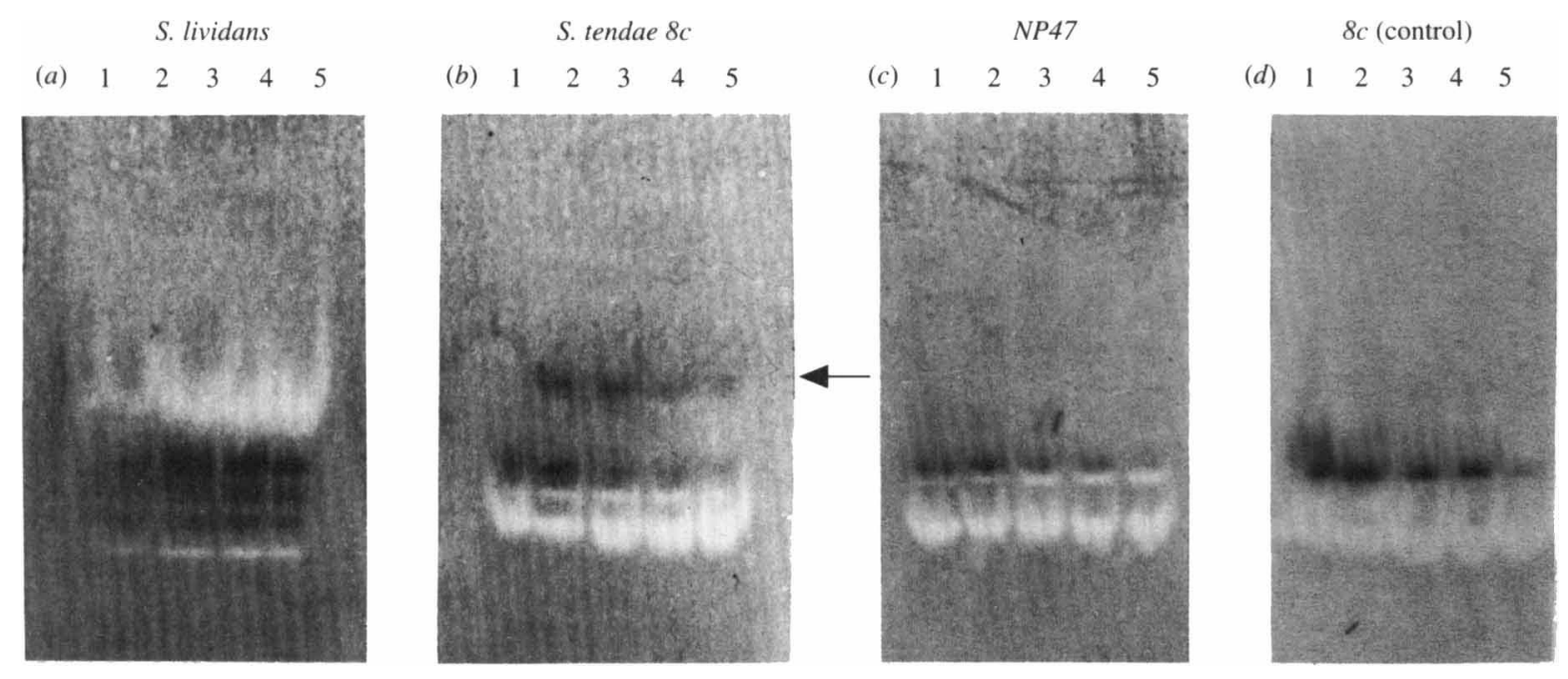

Fig. 1. Examination of crude cell extracts of $S$. lividans TK23, S. tendae Tü901/8c and NP47 for HisAT activity on non-denaturing polyacrylamide gradient gels. Lanes $1-5$ : extracts (135 $\mu$ g protein) from mycelium cultivated in SP medium for 17, 23, 41, 47 and $69 \mathrm{~h}$, respectively. Gels $(a)-(c)$ were stained with L-histidine and pyruvate; gel $(d)$ was stained with tyrosine and pyruvate. HisAT activity is marked by an arrow.

and describe the purification and properties of HisAT from crude extracts of $S$. tendae.

\section{Methods}

Organisms and conditions of cultivation. S. tendae Tü $901 / 8 c$ was obtained from the Streptomyces Culture Collection of the Institute of Microbiology I, University of Tübingen, Germany. S. tendae Tü901/ hut-11 is a histidine-ammonia-lyase-negative mutant (Roos et al., 1992) and Tü901/NP9, NP47 and NP55 are nikkomycin non-producing mutants (Bormann et al., 1989). S. lividans TK23 (Hopwood et al., 1985) was obtained from D. A. Hopwood, John Innes Institute, Norwich, UK.

For nikkomycin production, mycelia were grown in SM medium consisting of $3 \%(\mathrm{w} / \mathrm{v})$ mannitol, $1 \%(\mathrm{w} / \mathrm{v})$ starch, $2 \%(\mathrm{w} / \mathrm{v})$ soy bean meal, and $1 \%(\mathrm{w} / \mathrm{v})$ yeast extract, $\mathrm{pH} 6.0$, and in SP medium $(3 \%$ mannitol, $1 \%$ soluble starch, $0.5 \%$ soy peptone and $0.8 \%$ yeast extract, pH 6.0). S. lividans was grown in CRM medium (Bormann et al., 1990) and YEME (Hopwood et al., 1985).

Strains were usually cultivated in $500 \mathrm{ml}$ baffled Erlenmeyer flasks containing $100 \mathrm{ml}$ medium on a rotatory shaker $\left(120\right.$ r.p.m.) at $27^{\circ} \mathrm{C}$. However, for purification of HisAT, S. tendae Tü901/hut-11 was grown in 2 litre baffled Erlenmeyer flasks containing $500 \mathrm{ml}$ SP medium; cultures were inoculated with $5 \mathrm{ml}$ of a preculture grown in the same medium for $2 \mathrm{~d}$. At intervals during the large-scale culture, samples were taken for determination of HisAT activity. When the mycelium exhibited highest HisAT activity (Roos et al., 1992), it was harvested by centrifugation at $4500 \mathrm{~g}$ for $5 \mathrm{~min}$ at $4{ }^{\circ} \mathrm{C}$, washed twice with $100 \mathrm{~mm}-\mathrm{Tris} / \mathrm{HCl}, \mathrm{pH} 8.0$, and stored frozen at $-20^{\circ} \mathrm{C}$.

Enzyme assays. The assay for aromatic aminotransferases based on the method of Spolter \& Baldridge (1963) is described by Roos et al. (1992) but the concentrations of reactants are incorrect. The reaction mixture used in the present investigation to determine HisAT activity contained $0 \cdot 114 \mathrm{M}$-sodium tetraborate, $\mathrm{pH} 8 \cdot 0$, unless otherwise stated, $50 \mathrm{~mm}$-2-oxo acid, $100 \mathrm{mM}-\mathrm{L}$-histidine, $30 \mu \mathrm{M}$-pyridoxal-5'-phosphate and enzyme. Absorbance changes were monitored at $310 \mathrm{~nm}$. One unit of HisAT activity was defined as the amount of enzyme required to form $1 \mu \mathrm{mol}$ imidazolylpyruvate $\mathrm{min}^{-1}$ using the molar absorption coefficient $9.5 \times 10^{6} \mathrm{~cm}^{-2} \mathrm{~mol}^{-1}$ according to Lin et al. (1958).
The assay for transaminating activity with histidinol phosphate was as described by Ames \& Horecker (1956).

Protein was estimated by the method of Bradford (1976) with bovine serum albumin as standard.

Assay for aminotransferase activity on polyacrylamide gels. Electrophoresis using native polyacrylamide gradient gels has been described by Roos et al. (1992). The staining method for aminotransferase activity described by Gelfand et al. (1977) and Paris \& Magasanik (1981 a) was modified. Gels were stained at $37^{\circ} \mathrm{C}$ in the dark for $30-60 \mathrm{~min}$. The staining mixture contained $50 \mathrm{~mm}$-amino acid, $50 \mathrm{~mm}$-2-oxo acid, $0.19 \mathrm{~mm}$-pyridoxal phosphate, $0.48 \mathrm{~mm}$-thiazolyl blue, $0.098 \mathrm{~mm}$-phenazine methosulphate, $0.3 \mathrm{mM}-\mathrm{NAD}, 0.6 \mathrm{U}$ alanine dehydrogenase (Sigma) or $6 \mathrm{U}$ glutamate dehydrogenase (Sigma), and $100 \mathrm{~mm}$ Tris $/ \mathrm{HCl}, \mathrm{pH} 7 \cdot 5$, in a total volume of $50 \mathrm{ml}$. The dark-stained bands indicating aminotransferase activity were not detected in controls stained without 2-oxo acid.

Molecular masses were estimated using the high-molecular-mass protein standard from Pharmacia containing thyroglobulin $(669 \mathrm{kDa})$, ferritin $(440 \mathrm{kDa})$, catalase $(232 \mathrm{kDa})$, lactate dehydrogenase $(140 \mathrm{kDa})$ and bovine serum albumin $(67 \mathrm{kDa})$.

Purification of HisAT. All enzyme purification procedures were carried out at $4{ }^{\circ} \mathrm{C}$ unless otherwise indicated and all buffers, including those used for equilibration and elution, contained $10 \%$ (w/v) glycerol, $10 \mathrm{mM}$-EDTA and $1 \mathrm{mM}$-dithiothreitol (DTT).

Preparation of crude extract. Mycelium (180 g wet wt) was thawed in $180 \mathrm{ml} 100 \mathrm{~mm}$-Tris $/ \mathrm{HCl}$ buffer, $\mathrm{pH} 8.0$, containing $40 \%(\mathrm{w} / \mathrm{v})$ glycerol and $20 \mathrm{mM}$-EDTA, and ruptured by sonication on ice (Branson sonifier W-250;20\% duty cycle, power level 10 , three times for $2.5 \mathrm{~min}$ with a 2 min delay). Phenylmethylsulphonyl fluoride (PMSF) was added to a concentration of $2 \mathrm{~mm}$ to the crude extract, and cell debris was removed by centrifugation at $36000 \mathrm{~g}$ for $30 \mathrm{~min}$. Nucleic acids were precipitated from the supernatant by adding protamine sulphate [ $5 \%(\mathrm{w} / \mathrm{v})$ in $100 \mathrm{~mm}-\mathrm{Tris} / \mathrm{HCl}, \mathrm{pH} \mathrm{7.0]}$ to a final concentration of $0.2 \mathrm{mg}$ (mg protein) $)^{-1}$ and stirring the solution for $30 \mathrm{~min}$ on ice. The precipitate was removed by centrifugation at $20000 \mathrm{~g}$ for $15 \mathrm{~min}$.

Ammonium sulphate precipitation. Ground solid ammonium sulphate was added to the extract to $40 \%$ saturation with constant stirring over 
$30 \mathrm{~min}$. Following centrifugation at $20000 \mathrm{~g}$ for $15 \mathrm{~min}$, ammonium sulphate was added to $60 \%$ saturation in the same manner and centrifugation was repeated. The pellets were dissolved in $20 \mathrm{mM}-$ Tris/ $\mathrm{HCl}, \mathrm{pH} \mathrm{8.0.} \mathrm{The} \mathrm{solution} \mathrm{was} \mathrm{centrifuged} \mathrm{at} 100000 \mathrm{~g}$ for $30 \mathrm{~min}$ to remove particles which interfered with column chromatography, then it was desalted on a Sephadex G25 column $(5 \times 20 \mathrm{~cm})$ equilibrated with $20 \mathrm{mM}$-Tris $/ \mathrm{HCl}, \mathrm{pH} 8.0$, at a flow rate of $7.5 \mathrm{ml} \mathrm{min}^{-1}$.

$Q$-Sepharose chromatography. Protein-containing fractions from the Sephadex column were applied to a Q-Sepharose FF column $(2.6 \times 10 \mathrm{~cm})$ equilibrated with $20 \mathrm{~mm}-\mathrm{Tris} / \mathrm{HCl}, \mathrm{pH} 8.0$. Proteins were eluted with a linear gradient of $0-0.5 \mathrm{M}-\mathrm{NaCl}$ in the same buffer at a flow rate of $2.5 \mathrm{ml} \mathrm{min}^{-1}$. The total elution volume was $400 \mathrm{ml}$.

Butyl-Sepharose chromatography. Fractions containing HisAT activity from the Q-Sepharose column were pooled and ammonium sulphate was slowly added to a concentration of $1 \mathrm{M}$. The sample was applied to a butyl-Sepharose column $(1.6 \times 10 \mathrm{~cm})$ equilibrated with

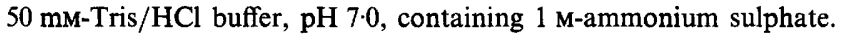
The column was eluted with $200 \mathrm{ml}$ of a linear gradient of $1-0 \mathrm{M}$ -

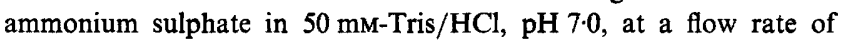
$0.2 \mathrm{ml} \mathrm{min}-1$. The active fractions were pooled and exchanged into $20 \mathrm{~mm}$-Tris $/ \mathrm{HCl}$ buffer, $\mathrm{pH} 8 \cdot 0$, using Pharmacia PD10 desalting columns.

Mono $Q$ chromatography. The enzyme preparation was loaded on a Mono $Q$ column $(1 \times 10 \mathrm{~cm})$ that had been equilibrated with $20 \mathrm{mM}$ Tris/HCl, $\mathrm{pH} \mathrm{8.0.} \mathrm{The} \mathrm{column} \mathrm{was} \mathrm{then} \mathrm{washed} \mathrm{with} \mathrm{equilibration}$ buffer, and proteins were eluted from the column with a linear gradient of $0-0.5 \mathrm{M}-\mathrm{NaCl}$ in $20 \mathrm{~mm}-\mathrm{Tris} / \mathrm{HCl}$ buffer, $\mathrm{pH} 8.0(80 \mathrm{ml})$. The flow rate was maintained at $1 \mathrm{ml} \mathrm{min}{ }^{-1}$.

Gel filtration. Active fractions obtained from the Mono $\mathrm{Q}$ column were exchanged into $20 \mathrm{mM}$-Tris/ $\mathrm{HCl}, \mathrm{pH} 8.0$, without glycerol. After lyophilization, protein was dissolved in $200 \mu \mathrm{l} 20 \mathrm{~mm}$-Tris/HCl, $\mathrm{pH} 8 \cdot 0$, and applied to a Superose 12 column $(1 \times 30 \mathrm{~cm})$ equilibrated with the same buffer. Gel filtration was performed at a flow rate of $0.1 \mathrm{ml} \mathrm{min}^{-1}$. For determination of the molecular mass of HisAT the column was calibrated with reference proteins from Sigma (blue dextran, $2000 \mathrm{kDa}$; $\beta$-amylase, $200 \mathrm{kDa}$; alcohol dehydrogenase, $150 \mathrm{kDa}$; carbonic anhydrase, $29 \mathrm{kDa}$ ).

PAGE. SDS-PAGE was carried out according to Laemmli (1970), using a $12 \%(\mathrm{w} / \mathrm{v})$ resolving gel and a $4 \%(\mathrm{w} / \mathrm{v})$ stacking gel. Molecular mass standards, obtained from Gibco BRL, were lysozyme $(14.3 \mathrm{kDa}), \beta$-lactoglobulin $(18.4 \mathrm{kDa})$, carbonic anhydrase $(29 \mathrm{kDa})$, ovalbumin $(43 \mathrm{kDa})$, bovine serum albumin $(68 \mathrm{kDa})$ and phosphorylase $b(97.4 \mathrm{kDa})$. Protein in gels was detected with Coomassie Blue G250.

\section{Results}

\section{Formation of HisAT in correlation to nikkomycin production}

Gel electrophoresis of cell extracts detected a protein specifically transaminating histidine only in nikkomycinproducing $S$. tendae Tü901 (Fig. 1). During cultivation in SP medium Tü $901 / 8 c$ produced about $400 \mathrm{mg}$ nikkomycin X plus $\mathrm{I}^{-1}$, and in SM medium $750 \mathrm{mg} \mathrm{l}^{-1}$. Crude extracts of the cells contained a protein band with HisAT activity and, in addition, AAT proteins that also reacted with tyrosine, tryptophan and histidine (data shown for SP medium). Only AAT proteins with broad substrate specificity were present in Tü901/8c cultivated in the complex HA medium that did not support nikkomycin production (data not shown). In cell extracts of the nonproducing mutants Tü901/NP9, NP47 and NP55 (Bormann et al., 1989) grown in production medium, only the multispecific AAT proteins were detected (data shown for NP47). Furthermore, a protein band transaminating histidine as sole substrate was not found in cell extracts of $S$. lividans cultivated in various media (YEME, CRM and SP) and harvested at different growth phases (Fig. 1; data shown for SP medium). The dark-stained bands on gels also appeared after treatment in the absence of a 2oxo acid, and thus were not due to aminotransferase activity.

\section{Purification of HisAT from S. tendae Tü901/hut-11}

S. tendae Tü901/hut-11 was cultivated in production medium and harvested at highest HisAT activity; the culture conditions and time of harvest have been described by Roos et al. (1992). HisAT activity, which was found to be rather unstable in cell extracts, could be stabilized in the presence of $20 \%$ glycerol, $10 \mathrm{mM}$ EDTA, $1 \mathrm{mM}$-PMSF and $30 \mu \mathrm{M}$-pyridoxal phosphate (Fig. 2). The steps of the purification procedure are listed in Table 1 and illustrated in Fig. 3. After precipitation of nucleic acids by protamine sulphate, fractionation was performed with ammonium sulphate at $40-60 \%$ saturation. The desalted enzyme fraction was applied to QSepharose and chromatographed with a linear $\mathrm{NaCl}$ gradient; HisAT activity eluted at approximately $0.15 \mathrm{M}$ $\mathrm{NaCl}$ with a sixfold purification. The active fractions, adjusted to $1 \mathrm{M}$-ammonium sulphate, were applied to butyl-Sepharose. Using a decreasing linear ammonium sulphate gradient, the active fractions eluted at about $0.3 \mathrm{M}-\left(\mathrm{NH}_{4}\right)_{2} \mathrm{SO}_{4}$ with a purification of about $7 \cdot 5$-fold. Fractionation by FPLC on Mono $\mathrm{Q}$ using a linear $\mathrm{NaCl}$ gradient eluted HisAT activity at approximately $0 \cdot 15 \mathrm{M}$ -

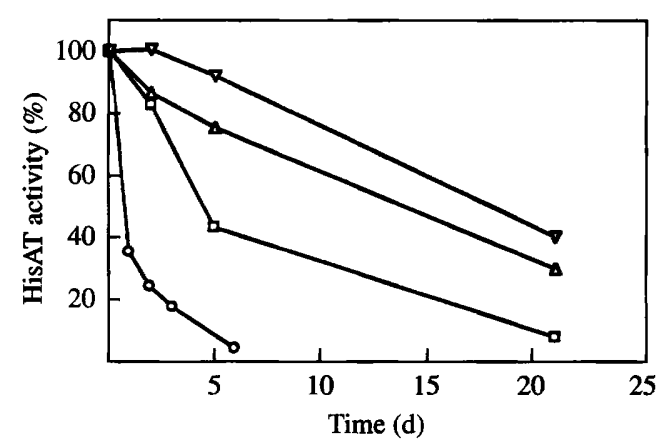

Fig. 2. Stabilization of HisAT activity in crude extract. Crude extract was prepared in $100 \mathrm{mM}-\mathrm{Tris} / \mathrm{HCl}, \mathrm{pH} 8.0$ and stored at $4{ }^{\circ} \mathrm{C}$ in the presence of the following: $O$, no further additions; $\square, 20 \%$ glycerol; $\triangle, 20 \%$ glycerol, 10 mM-EDTA, 1 mM-PMSF; $\nabla, 20 \%$ glycerol, 10 mM-EDTA, 1 mM-PMSF, $30 \mu$ m-pyridoxal phosphate. (100\% activity corresponded to $6 \mathrm{mU}$ HisAT.) 
Table 1. Purification of histidine aminotransferase

\begin{tabular}{|c|c|c|c|c|c|c|}
\hline Purification step & Vol. (ml) & $\begin{array}{l}\text { Total } \\
\text { activity } \\
(\mathrm{mU})\end{array}$ & $\begin{array}{l}\text { Total } \\
\text { protein } \\
(\mathrm{mg})\end{array}$ & 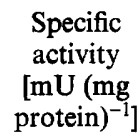 & $\begin{array}{l}\text { Purification } \\
\text { (-fold) }\end{array}$ & Yield (\%) \\
\hline Crude extract & 330 & 12018 & 2640 & $4 \cdot 5$ & 1 & 100 \\
\hline Ammonium sulphate & 86 & 5830 & 709 & $8 \cdot 2$ & 1.8 & 48.5 \\
\hline O-Sepharose & 52 & 3093 & $64 \cdot 3$ & $48 \cdot 4$ & 10.7 & $25 \cdot 7$ \\
\hline Butyl-Sepharose & 21 & 1499 & 4.05 & 372 & 83 & $12 \cdot 5$ \\
\hline Mono Q & 1.5 & 604 & 1.46 & 415 & 92 & $5 \cdot 0$ \\
\hline Superose-12 & 1.0 & 145 & $0 \cdot 17$ & 866 & 192 & $1 \cdot 2$ \\
\hline
\end{tabular}

(a)

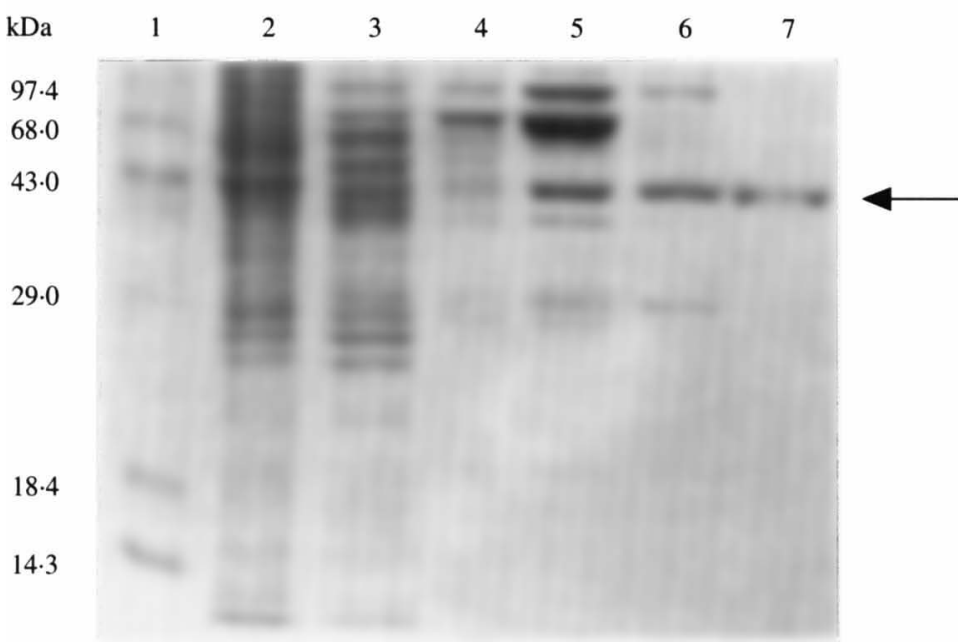

(b)

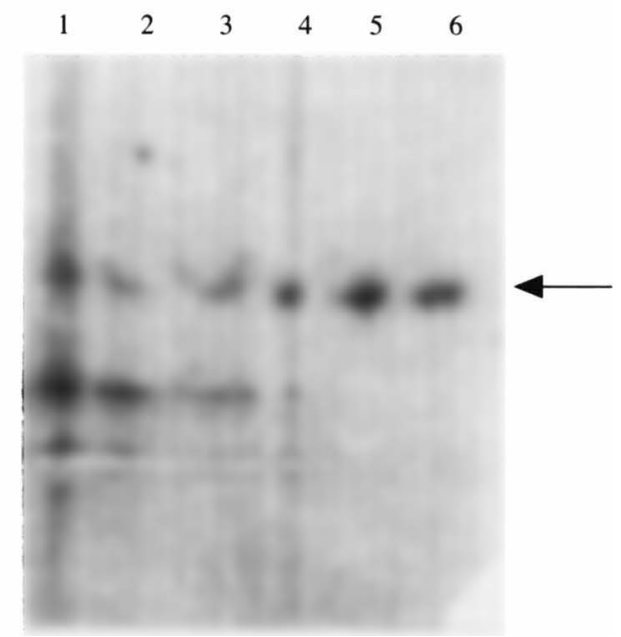

Fig. 3. Polyacrylamide gel electrophoresis of HisAT at different stages of purification. (a) SDS-PAGE stained with Coomassie blue. (b) Non-denaturing gradient PAGE stained for HisAT activity. Lanes: $2(a), 1(b)$ crude extract; $2(b)$ after ammonium sulphate precipitation; 3 $(a, b)$ after Q-Sepharose; $4(a, b)$ after butyl-Sepharose; 5(a,b) after Mono Q; 6(a,b) after Superose gel filtration; 7(a) HisAT band cut out from a native polyacrylamide gradient gel. (a) Lane 1, SDS-PAGE standards; lanes $1-5$, $5 \mu \mathrm{g}$ protein was separated; lane $6,0.5 \mu \mathrm{g}$ protein. (b) HisAT $(1 \mathrm{mU})$ was applied in each lane. HisAT is indicated by an arrow.

Table 2. Oxo acid specificity of partially-purified His AT

\begin{tabular}{lc}
\hline \hline Oxo acid (50 mM) & $\begin{array}{c}\text { Relative activity* } \\
\text { (\%) }\end{array}$ \\
\hline Pyruvate & 100 \\
2-Oxovalerate & 106 \\
2-Oxobutyrate & 101 \\
2-Oxocaproate & 95 \\
2-Oxoglutarate & 44 \\
Glyoxylate & 26 \\
2-Oxoisovalerate & 16 \\
\hline
\end{tabular}

* 100 mM-L-histidine was used as amino substrate. Activity on pyruvate $(23 \mathrm{mU})$ taken as $100 \%$.

$\mathrm{NaCl}$. This step resulted in a $2 \cdot 5$-fold loss of enzyme activity but separated HisAT from the multispecific AAT proteins (Fig. $3 b$ ). After gel filtration by FPLC, HisAT had been purified about 190 -fold from the crude extract with a recovery of $1 \%$. The final HisAT preparation showed two major contaminating protein bands in SDSPAGE gels stained with Coomassie blue (Fig. $3 a$ ).

The molecular mass estimated by gel filtration was approximately $85 \mathrm{kDa}$ for the native enzyme. The HisAT protein, which was identified by activity staining on a non-denaturing gradient gel, was excised from a parallel lane on the same gel upon Coomassie blue staining and subjected to SDS-PAGE. As a single protein band was obtained with a molecular mass of approximately $45 \mathrm{kDa}$ (Fig. $3 a$ ), the native enzyme is presumed to be a dimer of two identical subunits.

\section{pH and temperature optima}

The activity of the partially purified HisAT obtained after Mono Q chromatography was determined in borate buffer adjusted with $\mathrm{HCl}$ to $\mathrm{pH} 5 \cdot 5-8 \cdot 8$. The optimum activity was at $\mathrm{pH} 7 \cdot 2$. The optimum temperature for HisAT activity was $37^{\circ} \mathrm{C}$. 


\section{Substrate specificity}

In aminotransferase assays using the borate assay system with pyruvate as amino acceptor HisAT was highly specific for L-histidine and did not react with Lphenylalanine, L-tyrosine, L-tryptophan and D-histidine. In addition, HisAT did not react with L-histidinol phosphate using the assay of Ames \& Horecker (1956) for the formation of imidazolylacetol.

On gels HisAT had no activity towards L-alanine, Lleucine, L-lysine, L-glutamate and L-aspartate using pyruvate as amino acceptor, or towards L-aspartate with 2-oxoglutarate. In contrast, HisAT exhibited a broad specificity towards amino acceptor substrates. Similar activities were obtained with pyruvate, 2-oxobutyrate, 2 oxovalerate and 2-oxocaproate, but other 2-oxo acids could also serve as substrates (Table 2).

\section{Kinetic parameters}

Double-reciprocal plots of the initial velocity against the concentration of one substrate at a series of fixed concentrations of the second substrate gave a series of parallel straight lines. These Lineweaver-Burk plots indicated a ping-pong mechanism involving only binary substrate complexes (Cleland, 1963). Double reciprocal plots of the apparent $K_{\mathrm{m}}$ constants and apparent maximum velocities against the concentration of the second substrate gave straight lines, from which the concentration-independent $K_{\mathrm{m}}$ values for L-histidine and pyruvate were determined to be $25 \mathrm{~mm}$ and $10 \mathrm{mM}$, respectively.

\section{Discussion}

In primary metabolism of Streptomyces the first step in histidine catabolism is its non-oxidative deamination to urocanate and ammonia, which is catalysed by histidine ammonia-lyase (histidase; EC 4.3.1.3; Kendrick \& Wheelis, 1982). In addition to histidase, an aminotransferase with a narrow substrate specificity for Lhistidine as amino donor has been found in nikkomycinproducing $S$. tendae (Roos et al., 1992). Since histidine is known to be the precursor of the imidazolone base of nikkomycins (Schmidt \& Pape, 1985), we investigated whether there is a correlation between formation of HisAT and nikkomycin production. While HisAT protein was detected in $S$. tendae strains under nikkomycin production conditions in the early production phase, it was not found in non-producing mutants. As these strains are unable to form any of the known biosynthetic intermediates and cannot complement each other to form nikkomycin structures (unpublished results), they are suggested to be regulatory mutants or mutants with extensive genomic alterations. Therefore, enzymes involved in nikkomycin biosynthesis are not expected in these non-producers. Furthermore, a HisAT protein could not be detected in S. lividans grown under various conditions. This species is unable to synthesize nikkomycins. Although we cannot exclude that a HisAT activity band in gel electrophoresis gels was masked by one of the dark bands given by S. lividans extracts, and which are probably due to dehydrogenase activity, we conclude that HisAT is specific for nikkomycin producers.

We developed a purification procedure aimed at providing sufficient enzyme for partial characterization and amino acid analysis. The HisAT product obtained was purified from other aminotransferases present in the crude extract. However, two major contaminating proteins were still evident in SDS-PAGE gels. Attempts to remove them by chromatography on hydroxylapatite, ion-exchange and hydrophobic chromatography using various conditions were not successful. The low recovery of HisAT might be due to the fact that the HisAT activity measured in crude extract results from the combined action of HisAT and multispecific AAT proteins. Another possible reason is the instability of HisAT under the conditions used for chromatography, even with glycerol, EDTA and PMSF present.

Like AAT1 from $K$. aerogenes (Paris \& Magasanik, $1981 \mathrm{~b}$ ), and the asp $C$ and $t y r B$ gene product, the socalled aspartate and aromatic aminotransferase from $E$. coli $\mathrm{K} 12$, HisAT from $S$. tendae is composed of two identical subunits of approximately $45 \mathrm{kDa}$. The molecular structure of the histidine transaminating enzyme from $E$. coli $\mathrm{B}(81 \mathrm{kDa})$, L-histidine-2-oxoglutarate aminotransferase from Pseudomonas testosteroni $(70 \mathrm{kDa})$ and the AAT from Rhizobium leguminosarum $(53 \mathrm{kDa})$ have not been described (Wickramasinghe, $1969 a$; Hacking \& Hassall, 1975; Perez-Galdona et al., 1992). In general, there is a wide variation in the molecular masses of microbial AAT proteins, ranging from $33 \mathrm{kDa}$ (histidinol-phosphate aminotransferase from Bacillus subtilis; Weigent \& Nester, 1976) to $260 \mathrm{kDa}$ (AT-II from Corynebacterium flavum; Fazel \& Jensen, 1979).

Studies on the amino substrate specificity of the partially purified enzyme indicated that HisAT from $S$. tendae exclusively functioned with $\mathrm{L}$-histidine. No aminotransferase activity could be detected between histidinol phosphate and 2-oxoglutarate, the reaction catalysed by the imidazolylacetolphosphate-L-glutamate aminotransferase in histidine biosynthesis. Therefore, $S$. tendae HisAT activity is not attributed to this enzyme, as reported for Salmonella typhimurium (Albritton \& Levin, 1969).

Purified histidine-2-oxoglutarate aminotransferase 
from Pseudomonas testosteroni functioning in the degradation pathway of imidazolyl-L-lactate also exhibits high specificity for L-histidine, but it still retains slight activity towards phenylalanine, tyrosine and tryptophan (Hacking \& Hassall, 1975). It is also specific for 2-oxoglutarate as the amino acceptor whereas HisAT from $S$. tendae utilized pyruvate and several other 2-oxo acids to the same extent, but exhibited only about $40 \%$ of the activity with 2-oxoglutarate.

The kinetic parameters suggested a typical ping-pong mechanism of enzyme reaction. The Michaelis constants determined for histidine $(25 \mathrm{~mm})$ and pyruvate $(10 \mathrm{~mm})$ are unusually high. Even higher values for histidine were reported for the multispecific AAT1 from $K$. aerogenes (70 $\mathrm{mm})$ and the histidine-transaminating $E$. coli B enzyme (137 mM) (Paris \& Magasanik, $1981 b$; Wickramasinghe, $1969 a$ ). In contrast, the apparent Michaelis constants for histidine determined for the AAT1 from Rhizobium and the HisAT from Pseudomonas were $1.86 \mathrm{~mm}$ and $4 \mathrm{~mm}$ (Perez-Galdona et al., 1992; Hacking \& Hassall, 1975). The instability of HisAT during the purification procedure implies that the in vitro conditions used were not optimal for enzyme activity. This might also be a reason for the high $K_{\mathrm{m}}$ values obtained. Further investigations are needed to establish whether HisAT functions in nikkomycin biosynthesis. This should be resolved by isolation of the corresponding gene and the construction of mutants having the gene inactivated.

This work was supported by the Deustsche Forschungsgemeinschaft (SFB323, A4). We thank Elisabeth Knorpp for producing the photographs. We are also grateful to Reinhold Brückner for critical reading of the manuscript.

\section{References}

Albritton, W. L. \& Levin, A. P. (1969). Histidine-2-oxoglutarate aminotransferase activity in Salmonella typhimurium. Biochemical Journal 114, 662-664.

AMES, B. N. \& HoRECKER, B. L. (1956). The biosynthesis of histidine: imidazoleacetol phosphate transaminase. Journal of Biological Chemistry 220, 113-119.

BormanN, C., Mattern, S., Schrempf, H., Fiedler, H.-P. \& ZähNER, H. (1989). Isolation of Streptomyces tendae mutants with an altered nikkomycin spectrum. Journal of Antibiotics 42, 913-918.

BormanN, C., Aberle, K., Fiedler, H.-P. \& Schrempf, H. (1990). Genetic complementation of Streptomyces tendae deficient in nikkomycin production. Applied Microbiology and Biotechnology 32, 424-430.

BRADFORD, M. M. (1976). A rapid and sensitive method for the quantitation of microgram quantities of proteins utilizing the principle of protein-dye binding. Analytical Biochemistry 72, 248254.

Cleland, W. W. (1963). The kinetics of enzyme-catalyzed reactions with two or more substrates or products. Biochimica et Biophysica Acta 67, 104-137.
FAZEL, A. M. \& JENSEN, R. A. (1979). Aromatic aminotransferases in coryneform bacteria. Journal of Bacteriology 140, 580-587.

Gelfand, D. H. \& SteinBerg, R. A. (1977). Escherichia coli mutants deficient in the aspartate and aromatic amino acid aminotransferases. Journal of Bacteriology 130, 429-440.

HaCKING, A. J. \& HASSALL, H. (1975). The purification and properties of L-histidine-2-oxoglutarate aminotransferase from Pseudomonas testosteroni. Biochemical Journal 147, 327-334.

Hopwood, D. A., BibB, M. J., Chater, K. F., Kieser, T., Bruton, C. J., KieSER, H. M., Lydiate, D. J., SMith, C. P., WARD, J. M. \& SCHREMPF, H. (1985). Genetic Manipulation of Streptomyces-a Laboratory Manual. Norwich, UK: John Innes Foundation.

JeNSEN, R. A. \& CALHOUN, D. F. (1981). Intracellular roles of microbial aminotransferases: overlap enzymes across different biochemical pathways. Critical Reviews in Microbiology 8, 229-266.

KAMPS, H.-J. (1989). Untersuchungen zur Biosynthese von Nikkomycinen und zum Stoffwechsel von Streptomyces tendae. $\mathrm{PhD}$ thesis, Universität Münster, Germany.

KENDRICK, K. E. \& WHEELIS, M. L. (1982). Histidine dissimilation in Streptomyces coelicolor. Journal of General Microbiology 128, 2029-2040.

Kradolfer, P., Niederberger, P. \& Hutter, R. (1982). Tryptophan degradation in Saccharomyces cerevisiae: characterization of two aromatic aminotransferases. Archives of Microbiology 113, 242-248.

LAEMMLI, U. K. (1970). Cleavage of structural protein during the assembly of the head of bacteriophage T4. Nature, London 227, 680-685.

LeE, C.-W. \& Desmazeaud, M. J. (1985). Utilization of aromatic amino acids as nitrogen sources in Brevibacterium linens: an inducible aromatic amino acid aminotransferase. Archives of Microbiology 140, 331-337.

Lewis Kittell, B., Helinski, D. R. \& Ditta, G. S. (1989). Aromatic aminotransferase activity and indoleacetic acid production in Rhizobium meliloti. Journal of Bacteriology 171, 5458-5466.

Lin, E. C. C., PitT, B. M., Civen, M. \& Knox, W. E. (1958). The assay of aromatic amino acid transaminations and keto acid oxidation by the enol borate-tautomerase method. Journal of Biological Chemistry 233, 668-673.

Paris, C. G. \& Magasanik, B. (1981 a). Tryptophan metabolism in Klebsiella aerogenes: regulation of the utilization of aromatic amino acids as sources of nitrogen. Journal of Bacteriology 145, 257-265.

PARIS, C. G. \& MAGASANIK, B. $(1981 b)$. Purification and properties of aromatic aminotransferases from Klebsiella aerogenes. Journal of Bacteriology 145, 266-271.

Perez-Galdona, R., Corzo, J., Leon-Barrios, M. A. \& GutierrezNAVARRo, A. M. (1992). Characterization of an aromatic amino acid aminotransferase from Rhizobium leguminosarum biovar trifolii. Biochemie 74, 539-544.

Roos, U., Mattern, S., Schrempf, H. \& BormanN, C. (1992). Histidine aminotransferase activity in Streptomyces tendae and its correlation with nikkomycin production. FEMS Microbiology Letters 97, 185-190.

SCHMIDT, R.-M. \& PAPE, H. (1985). Biosynthesis of 4-formyl-4imidazoline-2-one, the heterocyclic base of nikkomycin X. Zeitschrift für Naturforschung 41c, 135-140.

Spolter, P. D. \& BaldRIDGe, R. C. (1963). The metabolism of histidine. Journal of Biological Chemistry 238, 2071-2074.

WeIGENT, D. A. \& Nester, E. W. (1976). Purification and properties of two aromatic aminotransferases in Bacillus subtilis. Journal of Biological Chemistry 251, 6974-6980.

WhITAKER, R. J., GaINES, C. G. \& JENSEN, R. A. (1982). A multispecific quintet of aromatic aminotransferases that overlap different biochemical pathways in Pseudomonas aeruginosa. Journal of Biological Chemistry 257, 13550-13556.

WiCKRAMASINGHE, R. H. (1969a). Studies on the histidine transaminating enzyme of Escherichia coli. Enzymologia 36, 161-171.

WICKRAMASINGHE, R. H. $(1969 b)$. Repressible histidine transamination in Escherichia coli and its retro-inhibition. Enzymologia 37, 91-96. 